\title{
Curriculum Evaluation of Light Vehicle Engineering Department with Discrepancy Model as Per Industry Needs
}

\author{
Anggi Aprianto ${ }^{*}$, Fahmi Rizal ${ }^{2}$, Remon Lapisa ${ }^{3}$, Ambiyar $^{4}$, Wakhinuddin Wakhid5, \\ Sukardi6, Afif Rahman Riyanda ${ }^{7}$
}

1,2,3,4,5,6 Faculty of Engineering, Padang State University, Indonesia

${ }^{7}$ Faculty of Teacher Training and Education, University of Lampung, Indonesia

\section{A R T I C L E I N F O \\ Article history: \\ Received 18 August z2020 \\ Received in revised \\ Form 30 September 2020 \\ Accepted 20 October 2020 \\ Available online 01 \\ November 2020 \\ Keywords: \\ Evaluation, Discrepancy \\ Model, Curriculum} curriculum majoring in light vehicle engineering as a whole is categorized as sufficient. Therefore, it needs a follow-up from the relevant parties for a better implementation.; one of which is by revising the curriculum to fit the needs of the industry.

\begin{abstract}
A B S T R A C T
The implementation of the curriculum as per industrial needs should be improved in terms of qualifications of teachers, tools, practicum materials, and the use of learning models as per industry needs. This study aims to evaluate the used curriculum of light vehicle engineering department as per industry needs. This study uses discrepancy evaluation model (design, installation, process, product and comparison) that describes the implementation of curriculum according to the industry needs from various aspects, namely: design, installation, process, product and comparison. The study results concluded that achievement level of curriculum implementation as needed in the design component obtained an average score of $4.28(83.17 \%)$ classed in a good category; installation components get an average score of $3,502(78.47 \%)$ classified in sufficient categories; process components get an average score of $4.05(81.75 \%)$ classed in a good category; and product components that scored an average of $4.02(81.26 \%)$ classified in a good category. As well as in the comparison component that obtained an average score of $3,324(74.27 \%)$ classified in sufficient categories. The implementation of vocational school
\end{abstract}

\section{Introduction}

One of the most important components of education system is curriculum. The curriculum is a school learning and planning guide that is prepared as a document applied in the classroom (Bryce et al., 2001; Buasuwan, 2018; Parkay et al., 2014; Vaporizki, 2019). The curriculum is designed to regulate the implementation of education system. The education system can run smoothly, so it can achieve the goal of qualified education. One of government's efforts in improving the quality of education is to improve the curriculum development that is closest to learning, namely schools (Wahzudik, 2018; Yudistira et al., 2016). The concept of curriculum development is the school determines school policy in order to improve the quality, and efficiency of education in order to modify the wishes of the community and establish close cooperation between schools, communities, industry, and the government in shaping the personality of learners. The needs of industrial world should be supported by a curriculum designed and developed with attention to content standards and graduate competency standards (Bhattacharyya, 2018; Triyono, 2016; Wardina et al., 2019). Thus, producing qualified graduates in accordance with the demands of DUDI and the needs of working world become the focus of vocational education.

Vocational education at SMK/MAK level and vocational education at higher level basically prepare graduates to have skills. The nature of vocational education must quickly adapt to changes (Curtis.R \& Crunkilton., 1984; Wardina et al., 2019). All institutions that produce human resources, including public education and vocational education, must change the paradigm of thinking in organizing education. The curriculum must be related to industry needs and economic agents in the future (Antara, 2019; Parkay et al., 2014).

Over the past decade, vocational high schools in Indonesia have been subjected to substantial criticism for the lack of adequate skills and knowledge of graduates that do not meet the industry needs. It 
resulting the employers to dissatisfy with the quality of vocational school graduates (Jatmoko, 2017; Syauqi et al., 2020; Wardina et al., 2019). In line with that, vocational education is prepared to produce graduates who are ready to work, have knowledge and especially skills that suit the needs of the industrial world as well as having good attitudes and behaviors (Murtinugraha, 2017; Yudistira et al., 2016).

The results of graduates are depending on the implementation of learning process in school. The education unit has a wide scope to develop the curriculum so that it suits the needs, circumstances, potentials, and conditions of learners (Curtis.R \& Crunkilton., 1984; Jatmoko, 2017). Based on observations made at Vocational Highschool 5 Pekanbaru, the school has not used the curriculum as per industry needs for the school has not cooperated with the industry yet, especially in the curriculum majoring in light vehicle engineering.

The review of link and match concept reflects the condition of cooperation between vocational highschool and industry that contains aspects of relevance in its implementation. Based on the concept of link and match between Vocational and Industrial High Schools, the vocational curriculum used should be based on the principle of relevance. This will be the basis for a variety of important decision-making that provides direction for the successful planning and implementation of the program at Vocational High Schools. Rapid development in the workplace requires continuous review of the existing curriculum to see if it is still relevant or not to the industry needs. Vocational education "fails" if its graduates are unable to meet the needs and the industry needs (Hang et al., 2018; Hariyati, 2018). Thus, link and match is very necessary in ensuring good cooperation between schools and industry (Fitzpatrick, 2004; Vaporizki, 2019). Therefore SMK is required to constantly develop its curriculum. Curriculum in the education system has a central role that must be considered carefully because the curriculum is the heart of education. A quality curriculum will produce qualified graduates (Wahzudik, 2018). One of the works of preparation and planning is to establish a curriculum development model that is in accordance with the field of expertise in the world of work so that there is sufficient synchronization and fulfillment of learning experience for its students (Triyono, 2016).

Referring to the various problems that occur in the field, it requires an in-depth evaluation related to the curriculum to fit the needs of the industry in SMK Pekanbaru City. Program evaluation is a systematic investigative activity about something valuable from an object (Muryadi, 2017). Improving the quality of learners' learning outcomes can be initiated by evaluating each component that can shape and influence the quality of learning through an evaluation, especially the evaluation of the program. Program evaluation is an effort to look at the level of implementation of a policy carefully by knowing the effectiveness of each component (Arikunto \& Cepi, 2010). Overall evaluation of the process of teaching and learning activities in SMK Negeri Jakarta judging from lesson plan, implementation of learning and evaluation of learning outcomes are classified as Very Good with an average of $80.13 \%$ (Murtinugraha, 2017). Assessment activities in the evaluation of the program are not only carried out at the end of the program activities, but should be done from the beginning, namely from the preparation of the program design, the implementation of the program and the results of the program (Muryadi, 2017).

This study aims to reveal the implementation of the curriculum in SMK Light Vehicle Engineering in accordance with the curriculum of the industry needs seen from the design, installation of this cooperation program reviewed from human resources (teachers and learners), facilities and infrastructure, revealing the implementation of the curriculum seen from the process, product components, and the comparative components. In general, the purpose of this study will bring and help the world of education, especially vocational schools in Pekanbaru city so that the competency standards of graduates suitable with the skills needed in the field.

\section{Methods}

The research produces recommendations for improvement of a program. It is focused on explaining the implementation of vocational school curriculum of light vehicle engineering department as per curriculum of industrial needs reviewed from Design, Installation, Process, Product and comparison. This research is expected to explain the picture of curriculum implementation in SMK Pekanbaru. The approach or method used in this research is quantitative method with descriptive approach. The study sampled 41 students. The type of data used in the evaluation of vocational school curriculum light vehicle engineering department as per industry needs is primary data, meaning that the data directly obtained from the research subject is students of SMK Negeri 5 Pekanbaru.

This study applies a discrepancy evaluation model. Discrepancy model is one of the evaluation models to look at the gap between the implementation and reality in school, which can later be made recommendations on improving the implementation of career guidance (Naser \& Utami, 2017). The 
implementation of individual learning plans in sample schools by $30 \%$ of the $100 \%$ standard means that the implementation of individual learning plans is very far below the standard set (Sugianto, 2015).

\section{Result and Discussion}

\section{Result}

Evaluation of vocational school curriculum majoring in light vehicle engineering is carried out to improve the quality of education as per industry needs. The purpose of this program evaluation is to explain the implementation of curriculum using a discrepancy model. A review of design, installation, process, product components, and comparisons are conducted using the model. The discussion of each component is described as follows.

First indicator, the curriculum objectives were obtained by TPR was $86.40 \%$ with excellent category. It means that the purpose of implementing the curriculum according to the needs of the industry in Pekanbaru vocational school has a very good goal for. Second indicator of curriculum needs with subindicators of the need for the implementation of productive learning obtained TPR value of $79.57 \%$ with a good category. Thus, the need for the implementation of productive learning is good because learners need competencies in the field of light vehicle engineering that will be used in the industrial world. Third indicator of facilities and pre-existing with sub-indicators namely the availability of facilities (internet, laptops, media trainees , and electricity networks) obtained TPR of $83.55 \%$ with a good category. It proves that in the learning program, it has adequate facilities although the school must continue to improve and adding other facilities that support the learning process. It is expected that with the complete facilities and pre-existing, students are able to optimize their potential.

Based on the data obtained, the indicators with sub-indicators of educators' background and competency get $81.07 \%$ TPR in a good category. It means that educators have a good educational qualifications and competencies in learning programs, and schools need to improve their skills so that the quality of learning can be better in the future. Indicators of learners with sub-indicators of learner background and competence obtained TPR $72.22 \%$ with sufficient categories. It means that the implementation of the industrial needs curriculum has a good quality of learners so they are able to follow the learning process. Based on the data of learning device indicators with sub-indicators syllabus and lesson plan obtained TPR of $82.12 \%$ with a good category. It shows that the quality of learning devices in the learning program in Pekanbaru city vocational school is good.

Indicators of the learning process with sub-indicators of industrial needs curriculum in Pekanbaru city vocational school obtained TPR by $80.85 \%$ with a good category. It means that the process of implementing the learning carried out in the laboratory goes well. Indicators of educator activity obtained TPR by $82.24 \%$ with a good category. That is, educator activities during learning have also been running well. It can be seen from the positive response from learners towards educator's activities in the teaching-learning process. Indicators of student activities with sub-indicators of infrastructure utilization in the implementation of learning in Pekanbaru city vocational school, based on data obtained by TPR of $82.16 \%$ is in a good category.

Product component in this study has one indicator/sub-indicator that is the learning level achievement results in Pekanbaru city vocational school. Based on the data, it obtained TPR value by $81.26 \%$ with a good category. It shows that the learning achievements of learners who follow the learning program are good. Impact indicators with sub-indicators of curriculum implementation as per industrial needs obtained by TPR of $74.27 \%$ are in sufficient categories.

\section{Discussion}

\section{Design Component (Design)}

The design component in this discussion is reviewed from three indicators, namely curriculum objectives, curriculum needs and infrastructure for the implementation of the curriculum as per industrial needs in Pekanbaru city vocational school. The first indicator is curriculum objectives that were obtained by TPR by $86.40 \%$ with excellent category. It means that the purpose of implementing the curriculum has a very good goal for students. Thus, the purpose of the curriculum as per industrial needs support the learners to have competencies in the field of light vehicle engineering. The remaining $13.60 \%$ of TPR that has not appeared in this research is influenced by other sub indicators such as planning, changes, formulation and priority goals. Therefore, the follow-up of the existing TPR needs to be conducted as an effort to optimize the objectives of the curriculum; operationally, the efforts carried out are to socialize the curriculum as per industrial needs to the learners who will learn the science of light vehicle engineering. That is, students who are in class $\mathrm{X}$ need to be given an explanation of the objectives of the curriculum so 
that later when the students are in grade XI and XII, they have known things related to the objectives of the curriculum as per industrial needs.

The second indicator of curriculum needs with sub-indicators for the implementation of productive learning obtained TPR value of $79.57 \%$ is classified in a good category. Thus, the need for the implementation of productive learning is good because learners need competencies in the field of light vehicle engineering that will be used in the industrial world. The remaining $20.43 \%$ of TPR that has not appeared in the research is influenced by other sub-indicators such as the needs of educators, learners, and learning needs. Therefore, the follow-up of the existing TPR should optimize the productive learning programs; operationally, the efforts made are analyzing the needs of educators and learners in productive learning programs. It means that the discussion need to be conducted with educators and learners for a higher productive learning program.

The third indicator of facilities and pre-existing with sub-indicators is the availability of facilities (internet, laptops, media Trainees,and electricity networks) which obtained TPR of $83.55 \%$ with a good category. It proves that in the learning program has adequate facilities. Although the school must continue to improve and add other facilities that support in learning, it is expected that with the complete facilities and pre-existing, students are able to optimize their potential. The remaining $16.45 \%$ of TPR that has not appeared in the study is influenced by other sub indicators such as financing of facilities, infrastructure, and effectiveness of the use of facilities and feasibility. With good facilities, student activities can be conducted smoothly (Gentili, 2017; Riyanda et al., 2020). By utilizing existing facilities, it is expected that the learning process can still be carried out properly. However, there needs to do efforts to optimize the facilities and infrastructure in the learning program in Pekanbaru city vocational school by giving input to the school related to the facilities and infrastructure that are needed in the learning program.

Design components aim to develop necessary resources to carry out the activities in achieving goals (Fitzpatrick, 2004). From the above discussion, it can be concluded that from the three indicators contained in the design component is quite good with a TPR score of $83.17 \%$, meaning that the program is successfully achieved its goal to create learners who have competencies in the field of light vehicle engineering and ready-to-use in the industrial world.

\section{Installation evaluation component}

The installation component of this study has three indicators namely educators, learners, and learning tools. Based on the data obtained educator indicators with sub-indicators of educator education background and competency educators get $81.07 \%$ TPR are categorized as good. It means that educators have good educational qualifications and competencies in learning programs and schools need to improve their skills so that the quality of learning can be better in the future. The remaining $18.93 \%$ of TPR that has not appeared in this study is influenced by other sub-indicators such as educator learning strategies, class mastery, and educator behavior. Therefore, there need to be efforts to optimize human resources in learning programs by providing support in the self-development of educators such as providing opportunities to attend training/training so that educators can be more competent in carrying out learning.

Indicators of learners with sub-indicators of learners' background and learners' competence obtained TPR $72.22 \%$ with sufficient categories. It means that the implementation of the curriculum as per industry needs has a good quality of learners so they are able to follow the learning. The remaining $27.78 \%$ of TPR that has not appeared in this study is influenced by other sub-indicators such as student characteristics, social ability, and initial ability of learners. Therefore, there needs to be an effort to optimize learners in the learning program by providing support in self-development of learners, among others, providing opportunities for learners to be able to express their opinions in every opportunity, either during discussions or presenting materials in front of the class.

Based on the data of learning device indicators with sub-indicators syllabus and lesson plan, it obtains TPR of $82.12 \%$ with a good category. It shows that the quality of learning devices of the learning program in Pekanbaru city vocational school is good. The remaining $17.88 \%$ of TPR that has not appeared in this research is influenced by other sub-indicators such as modules, job sheets, learning hangouts and semester, and yearly programs. Therefore, it is necessary to optimize the learning tools of learning programs in Pekanbaru vocational school by giving input to educators to realize much-needed learning tools in learning programs.

Based on three indicators and each sub-indicator of the installation component, it is stated that educators, learners, and learning devices are categorized sufficiently. The components of installation evaluation include human resources as well as the various procedures and rules needed to be done related to the comparison of problem solving strategies and designing relevant stages of activities and 
both in the implementation of vocational curriculum majoring in light vehicle engineering as per industry needs (Akhmetov et al., 2016; Widoyoko, 2010).

\section{Process evaluation components}

Process components in the research have three indicators/sub-indicators, namely learning process, educator activities, and student activities. Learning process indicators with sub-indicators of the curriculum implementation process as per industry need at Vocational School in Pekanbaru city obtained TPR by $80.85 \%$ with a good category. It means that the process of learning implementation that is carried out in the laboratory goes well. Other undiscussed sub-indicators in this research cause the non-optimal learning process in the implementation of the curriculum as per industrial needs in Pekanbaru city vocational school. Thus, the remaining $19.15 \%$ TPR that has not appeared in this research is influenced by other sub-indicators such as identifying obstacles in the implementation of activities, implementing relationships and learners as well as the provision of implementation decision data. Therefore, it is necessary to optimize the learning process in the implementation of learning programs in Pekanbaru Vocational School operationally. The efforts made are asking or discussing to learners about things that feel to be obstacles in the learning process. It means that students are asked to express their opinions about the learning process implemented such as methods, models, and learning strategies that need to be improved for a better learning process.

Indicators of educator activity obtained TPR by $82.24 \%$ with a good category. That is, educator activities during learning have also been running well. It can be seen from the positive response from learners about educator activities in the learning process. The remaining $17.76 \%$ of TPR that has not appeared in this research is influenced by other sub-indicators such as feedback from the efficiency of program implementation, implementation design, and documentation of procedures carried out. Therefore, it is necessary to optimize the activities of educators in the implementation of learning programs in Pekanbaru city vocational school, operationally. The efforts made are asking the educators to make news events during the implementation of learning and document practicum activities so that educator activities can be better than before.

Based on data obtained by TPR of $82.16 \%$ with a good category, the data about indicators of student activities with sub-indicators of infrastructure utilization in the implementation of learning in Pekanbaru city vocational school shows that the activities of learners run well in utilizing existing facilities so that the learning process can still be carried out properly in the laboratory. The remaining $17.84 \%$ of TPR that has not appeared in this research is influenced by other sub-indicators such as communication media in learning, schedule of activities, and standards of learning resources. Therefore, it is necessary to optimize the activities of learners in the implementation of learning programs in Pekanbaru city vocational school. Operationally, the effort made was that students are asked to make a time allocation plan at each implementation of practicum so that it is expected to be able to improve learner's activities in the learning program.

Based on three indicators / sub indicators of process components stated that the learning process, educator activities, student activities have been running well with an average TPR score of $81.75 \%$. However, the obstacles faced in the implementation of vocational school curriculum majoring in light vehicle engineering as per industry needs is still not as expected. However, the solution that has been given should be taken seriously by the school. The evaluation process is used to detect or predict the draft procedure or implementation design during the implementation stage of the program, providing information for decisions in overcoming obstacles and as an archive of procedures that have occurred in overcoming obstacles with the solutions offered (Riyanda et al., 2020).

\section{Product Component}

The product component in this study has one indicator / sub-indicator that is the learning level achievement results of Vocational School in Pekanbaru city. Based on the data, obtained TPR by $81.26 \%$ is in a good category. It shows that the learning achievements of learners who participate in the learning program are good. It means that students have been able to understand the purpose of learning. Some sub-indicators are not discussed in this study. It affects the implementation of learning programs of Vocational School in Pekanbaru city to be not optimal. Thus, the remaining $18.74 \%$ of TPR that has not appeared in this study is influenced by other sub-indicators such as attitude assessment, cognitive strategy, and verbal information. Therefore, it is necessary to optimize the results in the implementation of learning programs of Vocational School in Pekanbaru city, such as conducting a thorough assessment of students cognitive, affective, and psychomotor. 


\section{Comparison evaluation component}

Impact indicators and sub-indicators of curriculum implementation as per industrial needs TPR data results of $74.27 \%$ are classified in sufficient categories. There are other sub-indicators that have not been discussed in this research; it affects the implementation of learning programs at Vocational School in Pekanbaru city that is still not optimal, so the remaining $25.73 \%$ of TPR that has not appeared in this research is influenced by other sub-indicators such as conceptual criteria and instrumental criteria. Therefore, there needs to be an effort to optimize the impact in the implementation of learning programs at Vocational School in Pekanbaru city, such as the need for schools to improve the quality of learning programs at the school in terms of stimulating learners to improve the results and impact the implementation of the curriculum as per industrial needs. Based on the above indicators, it can be concluded that the impact obtained by students who have participated in the curriculum program suitable for industrial needs is good and positive. It can be indicated from the competence of students at Vocational School in Pekanbaru city.

\section{Conclusion}

Based on the results and discussion, the design component is quite good. It means that the program successfully achieved its goal to create learners who have competencies in the field of light vehicle engineering and ready-to-use in the industrial world. The installation component is reviewed from three indicators and each component of the sub-indicator stated that educators, learners, and learning devices are categorized as sufficient; this proves that there must be followed-up of related parties for the installation component to be better for the future. In the process component, it is stated that the learning process, educator activities, student activities are already running well. However, the obstacles faced in the implementation of vocational school curriculum majoring in light vehicle engineering that suitable to industrial needs curriculum is still not as expected. However, the solution that has been given should be taken seriously by the school. Furthermore, the product component of the research results showed that the learning achievements of learners who participated in the learning program were good. This means that students have been able to understand the purpose of learning. As well as in the comparison component: the impact of the implementation of the curriculum according to the needs of the industry is quite significant. It means that the impact obtained by learners who have followed the learning well and positively, it sees from the skills and competencies that the learners have. But it needs attention from the school to encourage the learning competence of learners.

\section{References}

Akhmetov, L. G., Kirillova, O. V., Kirillova, T. V., Varlamov, A. V., Kashina, S. G., Safin, R. S., \& Sharonov, I. A. (2016). The managerial mechanism of future competitive technical specialists vocational training: The russian experience. International Review of Management and Marketing, 6(2). https: //www.openrepository.ru/article?id=722347

Antara, N. T. (2019). Penelitian dan Pengembangan Industri. Indonesia Industrial Summit 2019.

Arikunto, S., \& Cepi. (2010). Dasar-Dasar Evaluasi Pendidikan (Revision). Bumi Aksara.

Bhattacharyya, E. (2018). Stakeholders perspective on communicative competence in industry 4.0: Walk the talk of informative technologists. Les Ulis: EDP Sciences. https: //doi.org/10.1051/shsconf/20185303001

Bryce, G. R., Gould, R., Notz, W. I., \& Peck, R. L. (2001). Curriculum guidelines for bachelor of science degrees in statistical science. The American Statistician, 55(1), 7-13. https://doi.org/10.1198/000313001300339879

Buasuwan, P. (2018). Rethinking thai higher education for thailand 4.0. Asian Education and Development Studies, 7(2), 157-173. https://doi.org/10.1108/AEDS-07-2017-0072

Curtis.R, F., \& Crunkilton. (1984). Curriculum development in vocational and technical education: Planning, content, and implementation. Allyn and Bacon Inc.

Fitzpatrick, J. L. (2004). Exemplars as case studies: Reflections on the links between theory, practice, and context. American Journal of Evaluation, 25(4), 541-559. https://doi.org/10.1177/109821400402500409 
Gentili, C. (2017). "Time out" for classical studies? The future of italian liceo classico in the 4.0 world. Estudios Sobre Educación. Estudios Sobre Educación, 33, 127-143. https://dadun.unav.edu/handle/10171/44345

Hang, N. P. T., Thuy, L. T., \& Tam, P. T. (2018). Impacting the industry 4.0 on the training quality and student's satisfaction at lac hong university. Journal of Management Information and Decision Sciences, 21(1), 1-18.

Hariyati, N. (2018). Using Social Exchange Theory To Describe Cooperation Partnership Strategy Between Vocational High School With Business/Industrial World. International Journal of Civil Engineering and Technology (IJCIET), 9(8), 668-679. https://www.researchgate.net/publication/327529527

Jatmoko, D. (2017). Relevansi kurikulum SMK kompetensi keahlian teknik kendaraan ringan terhadap kebutuhan dunia industri di Kabupaten Sleman. Jurnal Pendidikan Vokasi, 3(1), 21-28. https://doi.org/10.21831/jpv.v3i1.1572

Murtinugraha, R. E. (2017). Evaluasi Pelaksanaan Kurikulum 2013 pada SMK Negeri Program Keahlian Teknik Bangunan di Jakarta. Jurnal Pensil: Pendidikan Teknik Sipil, 6(1), 21-28. https://doi.org/10.21009/jpensil.v6i1.7250

Muryadi, A. D. (2017). Model Evaluasi Program Dalam Penelitian Evaluasi. Jurnal Ilmiah PENJAS, 3(1), 918. http://ejournal.utp.ac.id/index.php/JIP/article/view/538

Naser, M. N., \& Utami, F. P. (2017). Evaluasi Program Bimbingan Karier Discrepancy Model dalam Meningkatkan Kualitas Kinerja Konselor. Prosiding Seminar Bimbingan Dan Konseling, 1(1), 292302. http://pasca.um.ac.id/conferences/index.php/snbk/article/view/230

Parkay, F. W., Anctil, E. J., \& Hass, G. (2014). Curriculum leadership: Readings for developing quality educational programs. Prentice Hall Inc.

Riyanda, A. R., Herlina, K., \& Wicaksono, B. A. (2020). Evaluasi Implementasi Sistem Pembelajaran Daring Fakultas Keguruan Dan Ilmu Pendidikan Universitas Lampung. IKRA-ITH HUMANIORA: Jurnal Sosial Dan Humaniora, 4(1), 66-71. https://journals.upi-yai.ac.id/index.php/ikraithhumaniora/article/view/669

Sugianto, A. (2015). Evaluasi Program Individual Learning Plans terhadap Perencanaan Pendidikan Siswa Sekolah Menengah Pertama Negeri Se-Kota Barabai-Kalimantan Selatan: Discrepancy Model. Universitas Negeri Malang.

Syauqi, K., Munadi, S., \& Triyono, M. B. (2020). Students' perceptions toward vocational education on online learning during the COVID-19 pandemic. International Journal of Evaluation and Research in Education, 9(4), 881-886. https://doi.org/10.11591/ijere.v9i4.20766

Triyono, M. B. (2016). Pengembangan isi kurikulum pendidikan teknik alat berat berbasis kebutuhan industri. Jurnal Pendidikan Vokasi, 6(3), 355-363. https://doi.org/10.21831/jpv.v6i3.12159

Vaporizki, S. (2019). Manajemen Kurikulum Berbasis Industri Kreatif Pada Kompetensi Keahlian Kriya Kreatif Logam dan Perhiasan SMKN 12 Surabaya. Jurnal Dinamika Manajemen Pendidikan, 3(2), 87-71. https://journal.unesa.ac.id/index.php/jdmp/article/view/4560

Wahzudik, N. (2018). Kendala dan Rekomendasi Perbaikan Pengembangan Kurikulum di Sekolah Menengah Kejuruan. Indonesian Journal of Curriculum and Educational Technology Studies, 6(2), 87-97. https://doi.org/10.15294/ijcets.v6i2.26712

Wardina, U. V., Jalinus, N., \& Asnur, L. (2019). Kurikulum Pendidikan Vokasi Pada Era Revolusi Industri 4.0. Jurnal Pendidikan, 20(1), 82-90. https://doi.org/10.33830/jp.v20i1.240.2019

Widoyoko, J. D. (2010). The Education Sector: The fragmentation and adaptability of corruption. In The state and illegality in Indonesia (pp. 165-187). Brill.

Yudistira, R., Ramadhani, N., Indrayana, S. D., \& Hadi, W. (2016). Studi Kurikulum SMK Berbasis Industri Kreatif di Indonesia Timur. Imajinasi: Jurnal Seni, 10(2), 133-142. https://doi.org/10.15294/imajinasi.v10i2.8807 